\title{
Standing Up to Giants: Thailand's Exit from 20th Century War Partnerships
}

\author{
Palapan Kampan ${ }^{1}$ \\ ${ }^{1}$ National Institute of Development Administration, Bangkok, Thailand \\ Correspondence: Palapan Kampan, National Institute of Development Administration Research Center, 118 \\ Serithai Road, Klongchan, Bangkapi, Bangkok 10240, Thailand. E-mail: palapan2000@yahoo.com
}

Received: May 26, 2014 Accepted: June 23, 2014 Online Published: July 11, 2014

doi:10.5539/ass.v10n15p153 URL: http://dx.doi.org/10.5539/ass.v10n15p153

\begin{abstract}
This article examines the U.S.-Thai relationship through various changes, paying close attention to strategic military operations within the Kingdom and into neighbouring countries. Multifaceted impacts of American outsourcing and corporate expansion are discussed. Thailand's role in the War on Terror amid domestic political turmoil and global economic uncertainty draw questions of the value of the $20^{\text {th }}$ century relationship model. Controversy about undeclared wars within the United States supports argument that Thailand should further remove itself from American-led foreign wars. As the ASEAN partnership continues to play a more dominant role in Thai government policy, with regional concerns more relevant than transpacific issues, Thailand is urged to revise legislation to protect its own security and interests. Such a focus is expected to reestablish Thailand as a regional leader.
\end{abstract}

Keywords: ASEAN, defense economics, global conflict, international law, international relations

\section{Introduction}

"Drinking snake blood and beheading chickens with their teeth" (Tomlinson, 2014), the headline read atop pictures of American Marines participating in the jungle survival training portion of annual Cobra Gold exercises in Thailand. Faces suggested those military men were participating not only in survival training, but also in a cultural activity. Maybe one of them recalled a famous line from The Beach (Boyle, 2000) when Leonardo DiCaprio's character was asked to drink snake blood. Most of them had certainly heard horror stories from the Vietnam War era in the region, when jungle survival was a relevant skill. Others probably mistakenly thought, like many foreign visitors to Thailand, that drinking snake blood is a common practice. Contrary to that popular belief, it is rare to find a Thai person who has actually drank snake blood, as it is considered a rather savage ritual. In the same vein, serious jungle survival skills are of little importance to most Thais, who are urban (CIA, 2014) or rural village dwellers.

Hardcore military personalities the likes of which U.S. Marines are famous for are generally out of place in present-day Thailand. Aside from a recent border dispute with Cambodia (Note 1), and despite ongoing violence in the south (Sanford, 2013), even amid political protests throughout the Kingdom (Marshall, 2014), Thailand is a nation at peace. Strengthening of the Association of Southeast Asian Nations (ASEAN) (Note 2) as it prepares for the 2015 start of the ASEAN Economic Community (AEC) (Note 3) further reduces threat of intra-regional conflict. China's economic rise concurrently offers ASEAN members a competitive Asian superpower to align with, uprooting U.S. hegemony in the region (Layne, 2008). While the alliance with the United States is still valuable to Thailand, the scope of American influence needs to be re-evaluated to determine what is appropriate for Thailand and its people.

Joint military exercises like Cobra Gold are productive international initiatives which pose little risk, but other aspects of the U.S.-Thai relationship have not been so easy to gather support for. The partnership has shown many signs of dysfunction, such as historical allegations of U.S. involvement in narcotics trafficking throughout the Southeast Asian region (Note 4), protests over purported U.S. interference with Thailand's internal affairs (VOA, 2011), reports of secret CIA prisons in Thailand (Open Society Foundation, 2013), leaked U.S. Embassy cables regarding the Thai royal family (Marshall, n. d.) and subsequent claims that the U.S. has interest in overthrowing Thai sovereign institutions (Cartalucci, 2013). During the Cold War, political and military support from the United States was crucial to Thailand, but Thailand presently serves to benefit more from more rigid 
independence and removal from the American foreign policy agenda. On the other end, the United States has consistently overextended itself abroad and could benefit from a more passive governmental approach, relying instead on the private sector to define the relationship.

This article examines the U.S.-Thai relationship through various changes leading to the present reality, paying close attention to clandestine and strategic military operations within the Kingdom and into neighbouring countries. Analyses of relations focus on recent transitions from military toward economic cooperation. Multifaceted impacts of American outsourcing and corporate expansion are discussed. Thailand's role in the War on Terror amid domestic political turmoil and global economic uncertainty draw questions of the value of the $20^{\text {th }}$ century relationship model. Controversy over undeclared wars within the United States is explored as reason for Thailand to further remove itself from American-led foreign wars.

As the ASEAN partnership continues to play a more dominant role in Thai government policy, with regional concerns more relevant than transpacific issues, Thailand is advised to revise legislation to protect its own security and interests. Such a focus is expected to reestablish Thailand as a regional leader. The United States is urged to respect Thailand's territorial integrity and facilitate partnership based upon mutual economic and humanitarian interests rather than military objectives. With trade in mind, conclusions recommend Thailand take a neutral position on international conflict occurring outside of its borders.

\subsection{Methodology}

This is a piece of legal research, undertaken with objectives of understanding current and historical contexts of Thai-American relations, finding and analyzing compelling legal interests, and applying legal principles to proffer solutions intended to help relieve Thailand's domestic economic and social struggles. We approached issues relating to foreign war with the view that conflicts in epistemology and deontological ethics were unavoidable given well-known, profoundly opposing interests involved in international warfare. The morality of war is not under review in this article. However, virtue ethics and consequentialism are explored via qualitative review of legal and journalistic sources. Our analysis and conclusions rely upon pragmatic ethics, whereby we propose that norms, morals, and practices may be improved through inquiry.

Legal positivist and legal interpretivist models supported review and analysis of theories of law, from the international to municipal levels. When and where conflicts in laws or conflicts between law and practice were found, Article 38 of the Statute of the International Court of Justice provided a guide on prioritizing laws and principles. Jus ad bellum and jus in bello concerns were paramount at the international level, whereas Constitutional principles superseded statutory authority at the domestic level. When and where conflicts between laws and systems were found to be extremely complicated, we sought to gain a clear picture of overall circumstances, and used human rights principles as a heuristic. Therefore, the most deference was given to Chapter 1 of the United Nations Charter, the Geneva Conventions, Rome Statute of the ICC, and jus cogens principles of international law. Discussion and conclusions also drew upon philosophical and legal principles from Confucian Eastern traditions.

\section{An Historic Friendship}

Thailand, formerly called Siam, was the first Asian nation with which the United States had diplomatic interactions (Note 5). By 1839, the United States established a consular presence. Diplomatic relations officially commenced in 1882 (Note 6). Siam was major historical trading hub and American interests at the beginning were commercial in nature. Siam's resistance to colonization and subsequent suspicion of Western powers constrained the early relationship regardless of whether or not the United States had any classical colonial ambitions. Historically, State relations took a backseat to private commerce due to internal deficiencies in the structure of Siamese government and lack of substantive international law.

Since 1932, Thailand's unique and painful journey from absolute to constitutional monarchy, through military dictatorships and toward democracy repeatedly strained relations. In 1942, Thailand declared war on the United States, but the Thai Ambassador refused to deliver the declaration (Note 7). More recently, deteriorating security in Bangkok amid political unrest led the U.S. Embassy in Bangkok (2014) to issue various travel warnings. American 'meddling' has likewise spurred negative reactions among Thai people (Bangkok Post, 2013). Despite media coverage of fallout between these two allies, the bilateral relationship is alive and robust, only in need of updating.

\subsection{Contemporary Economic Relations}

The United States is home to more than 240 thousand Thai-born naturalized citizens (Gryn \& Gambino, 2012), many of whom make up the backbone of the bilateral trading system. In 2013, trade between the nations reached 
nearly 39 billion dollars, with Thailand enjoying a surplus of over 14 billion (U.S. Census Bureau, 2014). While Thailand ranks around $27^{\text {th }}$ among American trading partners for annual exports and $19^{\text {th }}$ for imports (U.S. International Trade Administration, 2014), the United States is consistently one of Thailand's top three export and import markets (Thai Public Relations Department, n. d.). The United States is also one of Thailand's top three foreign investors (Royal Thai Embassy Washington DC, n. d.). But, while trade is strong and growing, with Thailand appearing to benefit more from the partnership than the United States, stress of globalization is consistent.

\subsubsection{Free Market or Neocolonialism?}

Debate on the moral and ethical value of globalization is common. Humans presently face conflicts of ideals and paradoxical sets of choices in an increasingly globalized economy. Multinational corporations, oft portrayed as the 'bad guy', bring manifold changes to emerging and developing economies. Alongside exploitation of economies of scale comes exploitation of labor (World Vision, 2009), corruption (OECD, n. d.), and neocolonialism (Note 8). Pollution is outsourced with manufacturing to poorly-regulated markets (Hawkins, 2014).

Markets whose demand is not met by domestic firms become saturated with foreign goods, which satisfy consumers in the short term while creating long-term economic deficiencies. Market entry by domestic upstarts becomes increasingly difficult as existing rivalries dominate consumer preferences, especially in technologies. Lacking sufficient room for new entrants and expanded competition, oligopolies become the norm. For example, the Thai mobile phone market is dominated by mega-corporations Apple and Samsung so much that Thailand's own i-Mobile can only scarcely stay alive. All across Thailand, Central malls and hypermarkets showcase foreign-based retailers like Tesco, Nike and assorted luxury brands. Global franchise eateries like McDonald's, The Pizza Company, and KFC enjoy wild popularity while domestic Thai franchises are nearly unheard of.

Dependence on foreign direct investment (FDI) can enslave a market to the whims and demands of foreign entities. Capitalization on foreign economies is legal, but anticompetitive and corrupt practices are routine among those few dominant players in global markets. Developing nations are hitherto unequipped to tame the beasts of Wall Street, leaving much of the world subject to not only external influence but also a heavy amount of external control. This lack of control over one's own country is the source of much complaining, resentment, and protest which is unlikely to cease until a time when domestic consumers have more control over prices and domestic firms have more opportunity at home.

\subsection{Military Ties}

The Cold War period changed U.S.-Thai relations. Once a country which declared war on the United States, after WWII Thailand found itself in need of protection from communist powers which setup shop allover Southeast Asia. The United States in turn found the Kingdom a natural ally in anti-communist political argument. Although it is not known whether or not His Majesty King Bhumibol Adulayej's American birthplace (Kanchanapisek Network, 1999) lent itself to enhancement of Thai-U.S. military relations during the Cold War, one can surmise that such a coincidence did not hinder the alliance. A sort of codependence developed between these two unlikely bedfellows.

\subsubsection{Thailand's Role in Post WWII External Conflicts}

Thailand has never been a major military powerhouse but it has played various roles in foreign combat since WWII. Thailand sent small numbers of troops into the Korean War (U.S. Department of State, n.d.). The United States and Thailand became treaty allies via the short-lived Southeast Asian Treaty Organization (U.S. Department of State, n. d.), carrying only two Southeast Asian members. Centuries-old feuds have led to exchanges between Thailand and its neighbours in Myanmar and Cambodia (BBC, 2014). During the reign of Rama IX, no military engagement compares to the Vietnam War in terms of size, scope and duration. .

\subsubsection{Vietnam War Era}

In 1962, U.S. Defense Secretary and Thai Defense Minister forged a bond that defined bilateral relations for decades: fighting communism (Pellerin, 2012). By 1964, Thailand allowed American military bases on Thai soil (U.S. Embassy Bangkok, n.d.). The following twelve years - through 1976 when American troops withdrew from Thailand - were the most significant in the history of U.S.-Thai relations (Kislenko, 2004). In 1966, nearly 25,000 American troops were stationed in Thailand (CIA, 1966). By the mid-1960s, nearly 80 percent of American bombing missions into Vietnam and Laos were flown out of Thailand (Randolph, 1986). Thailand was the regional hub for covert U.S. operations (Leary, 2007). Some clandestine military, CIA, and paramilitary 
operations in Laos and Cambodia were known to have existed by Southeast Asian locals while kept secret from the American Congress and people (Banks, 2012).

Thailand's role as an R\&R destination for American GIs and the resulting brothel industry are well known (Jones, n. d.), but Thailand was also significantly involved in military activities in the region. From the early 1960s, the CIA coordinated paramilitary operations in Laos with Royal Thai Police Air Reconnaissance Unit (Holm, 2008). Roughly 38,000 Thai troops were sent to Vietnam between 1965 and 1972 (Ruth, 2010), approximately $30 \%$ of total military forces (CIA, 1966). The United States footed the bill for Thai military involvement with more than 3.5 billion dollars in aid between the mid-1950s and mid-1970s (Berger, 2004). The Vietnam War was the foundation for a legacy of military relations between the United States and Thailand, which relied on the anticommunist vision for 50 years (Pellerin, 2004). Turning the page has proved a serious challenge for the allies as they look to find a common vision for the future.

\subsubsection{War on Terror}

Thailand's role in the American-led War on Terror was small and short-lived. In 2003, Thaksin's administration initially authorized 886 Thai soldiers to be sent to Iraq, but later halved the number, sending mostly engineers and medical personnel as political opposition to the war mounted in Thailand (CNN, 2003). When two Thai engineers were killed in Iraq (BBC, 2003), public criticism of Thailand's involvement quickly followed. By 2005, all Thai troops withdrew (Katzman, 2007).

While domestic Thai criticism focused on the two casualties and perceived morality of the war, international controversy was sparked when Thailand was listed as a country in which secret CIA prisons were stationed. In all, 54 countries were said to have been involved in operating CIA "black sites", where suspected terrorists were held and tortured. Thailand's participation in these "extraordinary renditions" reportedly occurred between 2002 and 2004 (Open Society Foundation, 2013). The War on Terror may have inspired a great many patriots in the Western world, but it was nothing short of a debacle in far-away Buddhist Thailand. Fundamental differences between the U.S. and Thailand were exposed, signaling a parting of ways for the old war buddies.

\subsection{Divergent Approaches to Counter Terrorism Signal Changing Relationship}

The War on Terror was a definitive conflict in U.S.-Thai military relations where the two nations found themselves politically, socially and morally divided in ways they had not experienced during the Cold War. Wars in Iraq and Afghanistan seem irrelevant to the Thai population, which does not sense threat of international warfare within the peaceful ASEAN region (Chalk, 2013). Jihadist attacks are also a tricky problem to deal with for Thailand, which has endured insurgency in the South for more than a decade. Brutal American tactics which yield hundreds of thousands of casualties (Sheridan, 2013) are simply not appropriate for Thailand to utilize or support at home. Likewise, Thailand cannot justify violating basic human and civil rights of its own citizens like the United States has done with international terror suspects (Brown, 2012).

Whereas the American approach to antiterrorism is one based on foreign intervention, occupation, and high-priced, bloody military involvement, Thailand approaches the issue domestically with a similar attrition strategy, but with less firefights and casualties. If local residents in lands occupied by American troops disapprove of U.S. military actions, there is no direct effect in the U.S., but if Thai nationals in the south were subject to the same treatment as enemies and locals in Afghanistan and Iraq, the Kingdom could crumble. In Iraq, Afghanistan, Pakistan, Yemen and elsewhere, the U.S. demonstrated calculated, youthful lust for battle while Thailand showed ancient acceptance and understanding of terrorism at home.

Thailand's pacifist style of conflict mitigation evinced a perceived lack of legitimacy toward the American-led War on Terror. Indeed, American military activities in foreign territories have been widely criticized as violating international law (UNOHCHR, 2013). American scholars (Williams, 2011), veterans (Iraq Veterans against the War, n. d.), members of Congress (Paul, 2002; Kucinich, 2012) and the public (Dugan, 2013) have touted the wars in Iraq and Afghanistan as illegal and unacceptable since the beginning. Opposition to war is a rational constant through history, but voices of dissent in American conflicts since WWII, oddly enough, seem to have both American domestic and international law on their side whereas war supporters have neither. A brief inspection of legal argument against recent wars shows dysfunction within the American government which provides seemingly endless opportunities for Presidents to exploit ultimate power. Such exploits are reason to change.

\section{The Presidents' Wars}

The United States of America has formally declared war eleven times related to five instances - the War of 1812, the Mexican-American War of 1846, the Spanish-American war of 1898, World War I, and World War II - yet 
the United States military has conducted combat activities in hundreds of instances in foreign countries (Elsea \& Grimmett, 2007). These undeclared wars, often called "conflicts" but also admitted to be "wars," are initiated and controlled entirely by the executive branch with the President as commander in chief of the military. Congress authorizes the President to utilize military forces abroad via statutes and resolutions, though the legislative branch has failed to declare war in all but eleven U.S. military actions in foreign nations. Controversy results over Constitutionality of executive-led military actions.

Recent examples in Iraq and Afghanistan have spurred global controversy from the start. The War on Terror was a contributory cause of global financial crisis and continues contribute to political turmoil worldwide. Synergistic programs like the NSA surveillance (CBS News, 2014) alongside diplomatic cables leaked onto the internet eroded bonds of trust among nations and citizens. As the United States is faced with threats to its once hegemonic authority over global military, economic, and political landscapes (Kupchan, 2012), some legal experts look inwards and place blame at the top.

\subsection{Controversy over Constitutional Power}

The U.S. Constitution grants Congress the power to "declare war" (Note 9), whereas the executive is given no such authority under the Constitution. Once war is formally declared, the President has control over the military. None dispute these facts. Controversy lies in the Presidential and Congressional invocation of non-Constitutional agreements which transfer legislative power over war to the executive. While battles overseas rage onward through time, scholars, critics, public officials (Paul, 2010) and others argue about the implicit and explicit authority of the Presidency and therefore executive branch in matters of military.

The Constitution requires the President to "take care that the laws be faithfully executed" (Note 10). The President is also required to take an oath prior to entering office wherein he or she swears to "preserve, protect and defend the Constitution of the United States." (Note 11) The oath does not mention other laws, and thus it is foremost the President's duty to uphold the "supreme law of the land" (Note 12) which is the Constitution first and indirectly treaty law. Original intent of Constitutional founders regarding myriad issues is difficult to establish, and ultimately dependent upon the judicial interpretation of the time in which the debate over Constitutional meaning occurs. Nonetheless, explicit and literal definitions of the English language are more bounded than some people have argued.

Article II of the Constitution is short compared to Article I, and provides little detail regarding the powers of the President. Pertaining to the President's role in military, Article II mentions only a general duty that "the President shall be Commander in Chief of the Army and Navy of the United States, and of the Militia of the several States, when called into the actual Service of the United States" (Note 13). No explicit provisions are found in the Constitution which grant or transfer of legislative powers to the executive. Separation of powers mandates that each branch is co-equal to the other two branches, and they are intended to check and balance powers among them, but one may not usurp the power of another. Using separation of powers as a guide, we can easily argue that Constitutional language was purposefully drafted to withhold from the executive the power to make war (Rakove, 2009) in order to prevent abuse of power.

An important issue in the controversy over undeclared wars may well be the constitutionality of statutes like War Powers (Note 14) and the National Emergency Act (Note 15), which have aided Presidents in seizing legislative power to declare or start war after congressional authorizations such as Public Law 107-40 (Note 16). Ironically though, the War Powers Act and National Emergencies Act were ostensibly intended to limit the power of the Presidency after the Vietnam War abuses under the Nixon and Johnson administrations. Presidents have reportedly considered the War Powers Act as unconstitutional, though not favoring this position to reduce instance of undeclared war; no, in fact, "every President since Nixon has regarded the War Powers Resolution as an unconstitutional intrusion on his prerogatives regarding the use of force" (Ackerman, 2001). Whether or not Presidential prerogatives to make war are in conflict with original intent of Constitutional language is yet undecided by the judicial branch.

\subsection{1 "...to protect the liberty and security of the governed..."}

Unfortunately for proponents of peace, the law is limited regarding what can be done in an instance when there may be collusion between all three branches to violate the Constitution by simply ignoring a reasonably viable interpretation of Article $1 \S 8$. When a more obvious interpretation of the basic law of a nation is not applied, resulting in controversies such as those witnessed during War Powers actions, judicial review should occur or the effectiveness of a Constitutional system is minimized. However, judicial review is not explicitly provided for in the Constitution (U.S. Supreme Court, n. d.), and coincidentally or not, the Court has opted not to invalidate executive-made wars on Constitutional grounds. 
Whether originally intended or not, the executive has consistently wrested legislative power to initiate war, and the legislative has delegated such authority to the President resulting in an apparent violation of separation of powers. Airports Auth. v. Citizens (Note 17) held that "the ultimate purpose of this separation of powers is to protect the liberty and security of the governed". What to do when security and liberty are in conflict with one another remains a perplexing issue. When posed with the choice, Presidents generally choose security, thereby failing to protect liberty and uncovering a glitch in the system.

Until recently, resistance to curtailing executive power persisted based upon perceived rights and duties to protect American citizens from foreign combatants. But, a progressive humanitarian interpretation of the $14^{\text {th }}$ Amendment, once used to protect foreign businessman Yick Wo (Note 18), could be applied to "any person" anywhere, including outside of the jurisdiction of the States, therefore making virtually all foreign war unconstitutional because the practice does not support Constitutional principles: "nor shall any State deprive any person of life, liberty, or property, without due process of law" (Note 19).

The fact that American Constitutional law does not inherently apply to foreigners outside of the USA is not a contentious issue, but recent actions suggest that American laws may not apply to American citizens either. Notwithstanding serious opposition, the Obama administration has ordered drone strikes on multiple American citizens, whose Constitutional rights to due process were arguably violated (McKelvey, 2011). In a time of remote and covert warfare, rights violations are a daily occurrence and there is seldom justice available for victims (Rowley, 2013).

At the core of the larger controversy, one side argues that the executive has unilateral authority over the military, and that the President's powers were originally intended to be broad, so there is no legal problem with undeclared wars (Association of the Bar of the City of New York, 2002). The other side contends that the President has no power to initiate a war without congressional declaration. Critics have gone so far as to say that the American Presidency is an "imperialist" one (Prakash, 2006), which might help explain how the democracy often enough manifests hereditary rulers.

Through the years, numerous cases attempted to address fundamental issues of undeclared wars (Note 20). In McArthur et al $v$ Clifford et al (Note 21), Justice Douglass, dissenting, wrote "the spectre of executive war-making is an ominous threat to our republican institutions" and called the issue an "important constitutional problem." Voices of dissent oft appear voices of reason as the executive, with de facto support of the legislative, claims the President's constitutional authority is broad, that the "Constitution vests the President with the plenary authority, as Commander in Chief and the sole organ of the Nation in its foreign relations, to use military force abroad" (Note 22).

\subsection{Same Effect by Any Cause}

Whether or not Congress declared a war, whether compliant with international law or not, whether Constitutional or legal per se or not, the United States of America has been involved in over 140 undeclared war actions since the War Powers Act of 1973 was passed, more than 7 times as many such actions as the U.S. engaged in between WWII and promulgation of the War Powers Act. The practical result of this supposed 'curbing of excess in the executive branch,' has been an increase in such abuses compared to the period prior to the so-called remedy.

Gross violations of international law are likewise arguable. Since the War Powers and National Emergencies Acts, the United States lost an International Court of Justice decision in Nicaragua v USA (Note 23), but failed to comply with the ruling pursuant to United Nations Charter Article 94(1). Though the United Nations' general mission is "to save succeeding generations from the scourge of war", the United States as a member has consistently violated such general principles, especially in its defiance of provisions mandating peaceful resolutions such as Article 2(4) and Article 33(1). Via breach of treaty provisions, the U.S. ipso facto flouts its own Constitution again as per the supremacy clause (Note 24). Perhaps military strategy thus precluded American ratification of the Vienna Convention on the Law of Treaties, so the U.S. could invoke, without remorse or remedy, provisions of its internal law as justification for failure to perform treaty obligations (Note 25).

Instead of formal declarations of war by the legislative branch, as mandated by the Constitution, since 1976 "the President has been subject to certain procedural formalities in utilizing some statutorily delegated emergency authority" (Relyea, 2001). The President, after having satisfied those procedural formalities, has been in effect independently allowed to commence and control any scale and scope of military operations he so desires. Presidents submitted 128 reports to Congress under the War Powers Resolution as of September 2010 (Grimmett, 2010), President Clinton having submitted the most reports at that time. Ongoing NATO and other intervention 
in foreign nations are justified and intellectualized with these reports "consistent with the War Powers Resolution".

\subsubsection{Force of Habit}

Various UN Security Council Resolutions (i.e. 678 \& 1441) (Note 26) have been used to justify use of unilateral force, despite apparent conflicts with UN principles and Charter Articles while at the same time the wars have been roundly considered illegal by scholars and the media (Kingston et al, 2003). Notwithstanding the merits of arguments against, the literal legalities of these situations have been largely disregarded in favor of the status quo, which accepts such military campaigns. Comparison between Iraqi and Afghani wars and Vietnam have been consistent, which conjures a grim outlook for the image of American military, whose reputation was marred significantly by Abu Ghraib (Hersh, 2004) and Guantanamo Bay (ACLU, 2011) prison torture scandals. Likewise, the reputation of the American people was placed in jeopardy when Amnesty International (2010) urged the U.S. to begin criminal investigations on its own government personnel regarding the torture of prisoners, and when former President Bush canceled a visit to Geneva due in part to the potential that he could have been prosecuted for his role in incidents of torture (Amnesty International, 2011).

Former President Bush's 2004 election opponent, John Kerry, once famously testified to the Senate Committee on Foreign Relations regarding war crimes U.S. servicemen reportedly committed in Vietnam. According to Kerry and other veterans, servicemen routinely "raped, cut off ears, cut off heads, taped wires from portable telephones to human genitals and turned up the power, cut off limbs, [blew] up bodies, randomly shot at civilians, razed villages in fashion reminiscent of Ghengis Khan, shot cattle and dogs for fun, poisoned food stocks, and generally ravaged the countryside of South Vietnam" on a "day-to-day basis with the full awareness of officers at all levels of command" (Kerry, 1971). The United States has been accused of war crimes more than once (Human Rights Watch, 2001), though its position on the UN Security Council gives it power over various matters unequal to other member nations. For as long as the U.S. withholds ratification of the Rome Statute (Note 27), there is no forum for leaders to be tried except within the U.S., where the military brass enjoys freedom from punishment. In a like manner, non-recognition of ICJ jurisdiction over any case is considered an entitlement (Note 28).

The basic idea is that the United States of America has been abusing for a very long time, and virtually nothing can stop it. President Nixon famously decreed his own sovereign immunity, saying "when the president does it, that means it is not illegal" (Frost, 1977) despite there being no statutory nor Constitutional support for such presidential sovereign immunity under American law. In fact, Clinton v Jones (Note 29) showed that public officials, including Presidents, are not granted immunity under the law. Beneath the Federal level, the Minnesota Supreme Court (n.d.) found that the doctrine of sovereign immunity "no longer served a useful purpose", and that only "planning level" conduct could be protected by immunity, whereas "operational level" conduct could not. Nonetheless, few can imagine a day in which an American President is prosecuted for a war-related crime.

Nixon, who actually declared the war on drugs (LEAP, 2008) - a war that has lasted 40 years, cost over \$1 trillion and hundreds of thousands of lives, which even the U.S. Drug Czar Kerlikowske said hasn't been effective (CBS, 2010) - might be the President whom history experts portray as the most habitual and deplorable of violators of the Constitution, but other Presidents have consistently gone beyond explicit Constitutional provisions in their use of the military abroad. In 2007, Obama remarked that "the president does not have power under the Constitution to unilaterally authorize a military attack in a situation that does not involve stopping an actual or imminent threat to the nation", then later sent troops into Libya without Congressional approval (Yoo, 2012). We could easily argue that there was no "imminent threat" posed by Afghanistan, Iraq, Pakistan, Yemen or the majority of foreign targeted persons, but such arguments fall on deaf ears.

\subsubsection{Beating a Dead Horse}

Unfortunately for the United States, allies like Great Britain and Australia have had to accept that the war in Iraq was not objectively lawful from the start (Guardian, 2010), a truth which led to a public statement by General Sir David Richards in the UK that the war against the Taliban and al-Qaeda is not winnable, an opinion Sir Richards said Gen. David Petraeus shared as well (BBC, 2010). In sum, these wars were never legal or winnable and came with a price tag of about $\$ 6$ trillion (Bilmes, 2013), pushing the United States closer to bankruptcy every year, one of Osama bin Laden's goals (McLean, 2004). At some point, one must stop and question the value and legitimacy of leadership, and pursue alternatives in the event that one is being led into oblivion. 


\section{3 "The War Powers Resolution Really Does Not Work" (Note 30)}

It is too late to prevent occupation of Iraq and Afghanistan, but the future need not be written as the past has been. If the Presidents will not cease extra-Constitutional warring, Congress can circumvent such military disasters by passing new legislation or by seriously amending existing statutory language regarding so-called undeclared wars, which has been proposed (Kaine, 2013). However, Congress passed more than a decade worth of White House budgets funding undeclared War on Terror actions, thus there appears to be little will in the legislative branch to curtail military activity.

Courts are the third and final means of correcting the problem, but the majority of the issue is exempt from court decision under the doctrine of political question or due to lack of standing. Challenge on Constitutional grounds is theoretically possible, but the Supreme Court has yet to speak on any such controversy. Alas, the internal workings of the American government remain secretive, and progress toward peace appears more elusive with each passing term. As in-fighting and opaqueness plague the American landscape, foreign nations are best advised to pursue alternative means of securing and maintaining peace and stability.

\section{Moving On}

While Thailand grapples with its own domestic development and political concerns, the United States moves forward with what many consider a perpetual war campaign (Scahill, 2013). These two Cold War buddies have long parted ways philosophically. While the United States as a republic theoretically separates religion and state while rationalizing millions of deaths for its own economic advantage (Beaumont and Walters, 2007), Thailand is constitutionally bound to "patronize and protect Buddhism" (Note 31), making use of force difficult to justify.

Upon closer inspection, these States and people seem to have very little in common. Thailand and the U.S. are from entirely different schools demographically, geographically, linguistically, politically, religiously, historically and culturally. Only a common foe has ever bound them as more than mere trading partners, and that foe perished when the Soviet Union fell and the People's Republic of China opened its doors. As Thailand eyes developing and maintaining closer ties with re-emerging leaders like China and India, its relationship with the United States must naturally change to accommodate allies whose interests are more Asia-centric. While a breakup may not satisfy either country, Thailand and the U.S. appear to be headed toward a sort of separation or open relationship. As a developing nation, there are various options Thailand can pursue to strengthen its own position in such a time of change.

\subsection{New and Improved Thai National Security}

In order to enhance the internal security and integrity of the Thai state, the nation should adopt a domestic strategy more similar to that of great powers like the U.S., China, Russia and France. Thailand affirmed its own sovereignty in 1976 when American bases were closed, but further effort is needed in the name of Thai national security. As per $\S 77$ of the Thai Constitution (Note 32), foreign military should not be allowed to conduct any independent covert or overt activities within the Kingdom, nor should a foreign military lead any operations aside from joint training exercises. Although the Thai Constitution alone provides sufficient guidance on military independence, sui generis legislation may be required to implement stronger controls.

The National Human Rights Commission may require broader and more specific investigative power, including that for prevention (Note 33), in order to assure Thailand is not complicit in torture of prisoners of war. The Constitution (Note 34) mandates compliance with human rights conventions such as the Geneva Convention (Note 35), but implementing statutes (Note 36) may need revision in response to extraordinary renditions.

The CIA is best known for espionage, yet it has enjoyed phenomenal hospitality within Thailand, leading undoubtedly to conflicting interests between military and other institutions. The Internal Security Act (Note 37) could be used to mitigate effects of foreign agencies like the CIA, but various threats are probably overlooked due to the long-term presence of such organizations within Thailand, where Thai nationals don CIA, FBI and U.S. Army fashion apparel. New legislation is recommended to protect Thai independence, sovereignty, national security and interests (Note 38). A tactfully worded Espionage Act would likely support Thai Constitutional objectives, but semantic argument about what threatens or injures the Kingdom would need to be anticipated prior to promulgation (Note 39), considering that there are government personnel who do not prefer change.

\subsection{Restart}

Long before the Cold War plagued the Southeast Asian political front, prior to drawing of colonial boundaries, Thailand - then known as Siam - was a major trading hub. The Chao Praya mouth at the Gulf of Thailand makes Bangkok a natural port of rest, leisure and commerce in the region. Located in the heart of the Greater Mekong Subregion, Thailand is a gateway into Southeast Asia (Royal Thai Embassy Washington DC, 2011). Known as a 
popular international tourist destination (TAT, 2014), Thailand - "Detroit of the East" - also hosts major automotive manufacturing facilities (Kubota and Sugiyama, 2014) and seeks to attract more foreign and domestic investment.

As the Kingdom strives to re-emerge as a trade hub, intra-ASEAN and intra-Asian relationships are of incomparable importance. Chinese firms offer competition for infrastructure projects like the Trans-Asian Railway Network joining Kunming with Singapore through Bangkok (People's Daily Online, 2011). The China-ASEAN Free Trade Agreement (2010) (Note 40) is expected to yield \$1 trillion in annual bilateral trade by 2020 (Yafei, 2014). These new partnerships and opportunities make it impossible for Thailand to cling to outdated policies and strategic alliances. The only feasible option for the Thais is to go back to what they were once best known for - international commerce - and take note from the King's second home in Switzerland.

\subsubsection{Neutrality}

British Prime Minister Neville Chamberlain once famously said, "In war, whichever side may call itself the victor, there are no winners, but all are losers" (Oxford, 2013).

War and violence can be rationalized through religion, including in Buddhist traditions (Shadbolt, 2013). However, engaging in conflict invariably leads to bias, which is not a virtue of a judicious nation. By losing objectivity and impartiality, opponents subject themselves the paradoxical outcomes highlighted by Neville Chaimberlain. The Theravada Buddhist tradition, which nearly all Thais practice, teaches of various states of neutrality or equanimity characteristic of balance, impartiality, wisdom and avoidance of excess (Gunaratana, 1980). Neutrality appears the only rational path for those who seek to commit themselves to orders of peace, justice, and respect for the rights of self and others.

Ideals of self-reliance and independence similarly form the basis of core American philosophy by Emerson and Thoreau. Although the American government has not taken initiative to preach such virtues in its missions abroad, nations like Thailand should take note of the one-way street that is American military activity. Certainly no foreign nation will ever be permitted to have a military base within the United States, nor would the American public tolerate foreign intelligence gathering within American borders. It is fact that a hypocritical United States applies its double standard with international impunity (Herman and Robles, 2013), in conflict with American internal law and against public opinion. However, engaging this debate is like opening Pandora's Box - it basically causes more trouble than it is worth.

\section{Conclusion}

"When you are content to be simply yourself and don't compare or compete, everybody will respect you." Lao $\mathrm{Tzu}$

In summary, Thailand is best advised to distinguish itself from the crowd by withdrawing from the military aspects of foreign affairs, by not taking sides, and by focusing on business. Nothing in all of history compares to the American war machine. One country in Southeast Asia certainly cannot steer the course of such a thing's future. All Thailand can do is try to stay away from external threats, whether direct or indirect. The United States should and will continue to be an ally and important trade partner, but Thailand's role in American conflicts should be nil since Thailand has no interest in associated risks. A shifting of Thailand's mental and human resources away from war games and imagined hostilities will free up more time and energies to focus on what is crucially important to the nation - finance, economics, and sustainable development.

\section{References}

ACLU. (2011). Accountability for Torture. Retrieved March 8, 2014, from http://www.aclu.org/accountability/ tortureprogram.html

Ackerman, D. (2001). Response to Terrorism: Legal Aspects of the Use of Military Force. CRS Report for Congress. Retrieved March 8, 2014, from http://fpc.state.gov/documents/organization/6217.pdf

Amnesty International. (2010). U.S. must begin criminal investigation of torture following Bush admission. Retrieved March 8, 2014, from http://www.amnesty.org/en/news-and-updates/us-must-begin-criminalinvestigation-torture-following-bush-admission-2010-11-10

Amnesty International. (2011). President Bush Cancels Visit to Switzerland. Retrieved March 8, 2014, from http://www.amnesty.org/en/news-and-updates/president-bush-cancels-visit-switzerland-2011-02-06

ASEAN Secretariat. (2012). Overview. Retrieved March 8, 2014, from http://www.asean.org/asean/about-asean

ASEAN Secretariat. (2012). ASEAN Economic Community. Retrieved March 8, 2014, from 
http://www.asean.org/communities/asean-economic-community

Association of the Bar of the City of New York. (2002). The Legality and Constitutionality of the President's Authority to Initiate an Invasion of Iraq. Retrieved March 8, 2014, from http://www.abcny.org/pdf/ ABCNY\%20Iraq\%20Report.pdf

Bangkok Post. (2013, December 19). Protestors Tell U.S. to Butt Out. Retrieved March 8, 2014, from http://www.bangkokpost.com/breakingnews/385680/protest-outside-us-embassy-in-bangkok

Banks, W. (2012). Shadow Wars. 5 Journal of National Security Law and Policy. Retrieved March 8, 2014, from http://jnslp.com/wp-content/uploads/2012/01/Introduction.pdf

BBC. (2003, December 30). Bodies of Thai Iraq dead returned. Retrieved March 8, 2014, from http://news.bbc. co.uk/2/hi/asia-pacific/3355961.stm

BBC. (2010, November 14). West cannot defeat al-Qaeda. Retrieved March 8, 2014, from http://www.bbc.co. uk/news/world-middle-east-11751888

BBC. (2014, May 22). Thailand Profile. Retrieved March 7, 2014, from http://www.bbc.com/news/world-asia15641745

Beaumont, P., \& Walters, J. (2007). Greenspan admits Iraq was about oil, as deaths put at $1.2 \mathrm{~m}$. The Guardian. Retrieved March 8, 2014, from http://www.theguardian.com/world/2007/sep/16/iraq.iraqtimeline

Berger, M. (2004). The Battle for Asia: From Decolonization to Globalization. NY, USA: RoutledgeCurzon.

Bilmes, L. (2013). The Financial Legacy of Iraq and Afghanistan: How Wartime Spending Decisions Will Constrain Future National Security Budgets. HKS Faculty Research Working Paper Series RWP13-006. Retrieved March 8, 2014 from https://research.hks.harvard.edu/publications/workingpapers/citation.aspx? PubId $=8956 \&$ type $=$ WPN

Boyle, D. (2000). The Beach [Motion picture]. 20th Century Fox Studios.

Brown, J. (2012). Official Statement from UK Foreign Office. Retrieved March 7, 2014, from https://www.gov.uk/government/news/jeremy-browne-torture-violates-human-rights-and-human-dignity

Cambodia v. Thailand, International Court of Justice (2013).

Cartalucci, T. (2013). Thailand's Military - An Important Independent Institution. Global Research. Retrieved March 8, 2014, from http://www.globalresearch.ca/thailands-military-an-important-independent-institution/ 5360806?print=1

CBS. (2010, May 13). War on Drugs Unsuccessful. Retrieved March 8, 2014, from http://www.cbsnews.com/ stories/2010/05/13/politics/main6480889.shtml

CBS News. (2014). NSA surveillance exposed. Retrieved March 8, 2014, from http://www.cbsnews.com/ feature/nsa-surveillance-exposed/

Chalk, P (2013). The U.S. Army in SE Asia. RAND. Retrieved March 8, 2014, from http://www.rand.org/ content/dam/rand/pubs/research_reports/RR400/RR401/RAND_RR401.pdf

Chamberlain, N. (1938). as quoted by Oxford (2013). Retrieved March 8, 2014, from http://www.oxfordreference.com/view/10.1093/acref/9780191735240.001.0001/q-oro-00002794

China-ASEAN Free Trade Agreement. (2010). Retrieved March 8, 2014, from http://www.dti.gov.ph/dti/index. $\mathrm{php} ? \mathrm{p}=688$

CIA. (1966). Communist Insurgency in Thailand, National Intelligence Estimate 5266. Retrieved March 8, 2014, from http://www.foia.cia.gov/sites/default/files/document_conversions/89801/DOC_0000012498.pdf

CIA World Factbook. (2014). Urbanization. Retrieved March 8, 2014, from https://www.cia.gov/library/ publications/the-world-factbook/fields/2212.html

Clinton v. Jones (95-1853), 520 U.S. 681 (1997).

CNN. (2003). Thai troops join Iraq force. Retrieved March 8, 2014, from http://edition.cnn.com/2003/WORLD/ asiapcf/southeast/09/04/sprj.irq.thai.troops/

Cohen, T. (2014, February 11). When can a government kill its own people? CNN. Retrieved March 8, 2014, from http://edition.cnn.com/2014/02/10/politics/us-killing-americans/

Commonwealth of Massachusetts v Melvin R. Laird, 400 U.S. 886 (1970). 
Congressional Record Volume 144, Number 56, Pages H2944-H2978 (May 7, 1998). Retrieved March 8, 2014, from http://www.gpo.gov/fdsys/pkg/CREC-1998-05-07/pdf/CREC-1998-05-07.pdf

Dugan, A. (2013, March 18). On $10^{\text {th }}$ Anniversary, 53\% in U.S. See Iraq War as Mistake. Gallup. Retrieved March 8, 2014, from http://www.gallup.com/poll/161399/10th-anniversary-iraq-war-mistake.aspx

Elizabeth Holtzman et al v James R. Schlesinger et al, 414 U.S. 1304, 94 S.Ct. 1, 38 L.Ed.2d 18 (1973)

Elsea, J., \& Weed, M. (2007). Declarations of War and Authorizations for the Use of Military Force: Historical Background and Legal Implications. CRS Report for Congress. Retrieved March 8, 2014, from http://www.fas.org/sgp/crs/natsec/RL31133.pdf

Ernest Da Costa v. Melvin R. Laird, Individually, and as Secretary of Defense of the United States, 405 U.S. 979 (1972).

Frost, D. (1977). Great Interviews of the $20^{\text {th }}$ Century. The Guardian. Retrieved March 8, 2014, from http://www.guardian.co.uk/theguardian/2007/sep/07/greatinterviews1

Gary F. Mottola et al v Richard M. Nixon and Melvin Laird, 464 F. 2d 178 (1972).

Geneva Convention (III) on Prisoners of War (1949).

Greenblatt, A. (2011, June 16). Why the War Powers Act doesn't work. NPR. Retrieved March 8, 2014, from http://www.npr.org/2011/06/16/137222043/why-the-war-powers-act-doesnt-work

Grimmett, R. (2010). War Powers Resolution: Presidential Compliance. CRS Report for Congress. Retrieved March 8, 2014, from http://www.fas.org/sgp/crs/natsec/RL33532.pdf

Gryn, T., \& Gambino, C. (2012). The Foreign Born From Asia: 2011. U.S. Census Bureau. Retrieved March 8, 2014, from https://www.census.gov/prod/2012pubs/acsbr11-06.pdf

Guardian. (2010). Iraq invasion violated international law. Retrieved March 8, 2014, from $\mathrm{http} / /$ www.guardian.co.uk/world/2010/jan/12/iraq-invasion-violated-interational-law-dutch-inquiry-finds

Gunaratana, H. (1980). A Critical Analysis of the Jhanas. The American University College of Arts and Sciences, Washington DC. Retrieved March 8, 2014, from http://www.buddhanet.net/pdf_file/printguna.pdf

Hamdi v. Rumsfeld, 542 U.S. 507 (2004).

Hawkins, R. (2014). IPCC: CO2 emissions are being 'outsourced' by rich countries to rising economies. PIRC. Retrieved March 8, 2014, from http://publicinterest.org.uk/ipcc-co2-emissions-outsourced-rich-countries -rising-economies/

Herman, E., \& Robles, J. (2013). WMD Double Standards: U.S. War Crimes and the Extensive Use of Chemical Weapons against Civilians. Global Research. Retrieved from http://www.globalresearch.ca/wmd-doublestandards-u-s-war-crimes-and-the-extensive-use-of-chemical-weapons-against-civilians/5348974

Hersh, S. (2004, May 10). Torture at Abu Ghraib. The New Yorker. Retrieved March 8, 2014, at http://www. newyorker.com/archive/2004/05/10/040510fa_fact

Holm, R. (2008). Recollections of a Case Officer in Laos, 1962-1964. CIA. Retrieved March 8, 2014, from https://www.cia.gov/library/center-for-the-study-of-intelligence/csi-publications/csi-studies/studies/vol47no 1/article01.html

Human Rights Watch. (2001). U.S.: Urgent Need for Vietnam Investigation. Retrieved March 8, 2014, from http://www.hrw.org/en/news/2001/05/07/us-must-investigate-alleged-war-crimes

Iraq Veterans against the War. (n. d.). Retrieved March 8, 2014, from http://www.ivaw.org/about/why-we-areagainst-wars

Jones, P. (n. d.). The U.S. Military and the Growth of Prostitution in Southeast Asia. ECPAT-USA. Retrieved March 8, 2014, from http://www.jbu.edu/assets/faculty/resource/file/faculty_profiles/preston_jones/navy_ and_asia.pdf

Joyner, J. (2011, May 11). How perpetual war became U.S. ideology. The Atlantic. Retrieved March 8, 2014, from http://www.theatlantic.com/international/archive/2011/05/how-perpetual-war-became-us-ideology/238 $600 /$

Kaine, T. (2013). Kaine announces joint effort with McCain to reform War Powers Resolution. U.S. Senate. Retrieved March 8, 2014, from http://www.kaine.senate.gov/press-releases/kaine-announces-joint-effortwith-mccain-to-reform-war-powers-resolution 
Kanchanapisek Network. (1999). Biography of His Majesty King Bhumibol Adulyadej. Retrieved March 8, 2014, from http://www.kanchanapisek.or.th/biography/hmk

Katzman, K. (2007). Iraq at the Crossroads. NY, USA: Nova Science.

Kerry, J. (1971). Vietnam Veterans Against the War Statement. PBS. Retrieved March 8, 2014, from http://www.pbs.org/wgbh/amex/vietnam/psources/ps_against.html

Kingston, et al. (2003). This war is illegal. Retrieved March 8, 2014, from http://www.smh.com.au/articles/2003/ 03/21/1047749933699.html

Kislenko, A. (2004). A Not So Silent Partner: Thailand's Role in Covert Operations, Counter-Insurgency, and the Wars in Indochina. Journal of Conflict Studies, 24, 1.

Kubota, Y., \& Sugiyama, K. (2014, January 21). Toyota warning on Thai crisis reveals frustration, limited options. Reuters. Retrieved March 8, 2014, from http://www.reuters.com/article/2014/01/21/us-japan-autos -thailand-idUSBREA0K0TL20140121

Kucinich, D. (2012, October 2). Iraq: Ten years, a million lives and trillions of dollars later. Huffington Post. Retrieved March 8, 2014, from http://www.huffingtonpost.com/rep-dennis-kucinich/iraq-ten-years-amillion_b_1932280.html

Kupchan, C. (2012, March 20). The Decline of the West: Why America Must Prepare for the End of Dominance. The Atlantic. Retrieved March 8, 2014, from http://www.theatlantic.com/international/archive/2012/03/ the-decline-of-the-west-why-america-must-prepare-for-the-end-of-dominance/254779/

Layne, C. (2008). China's Challenge to U.S. Hegemony. Current History. Retrieved March 8, 2014, from http://acme.highpoint.edu/ msetzler/IR/IRreadingsbank/chinauscontain.ch08.6.pdf

Law Enforcement against Prohibition (2008). Milestone days in the drug war: Nixon declares war on drugs. Retrieved March 8, 2014 from http://www.leap.cc/cms/index.php?name=News\&file=article\&sid=65

Leary, W. (2007). CIA Air Operations in Laos, 1955-1974. CIA. Retrieved March 8, 2014, from https://www.cia. gov/library/center-for-the-study-of-intelligence/csi-publications/csi-studies/studies/winter99-00/art7.html

Marshall, A. (n. d.) Thailand's Moment of Truth. Wikileaks. Retrieved March 8, 2014, from http://wikileaks.org/Thailand-s-Moment-of-Truth-Part,110.html

Marshall, A. (2014, January 14). Prognosis for divided Thailand bleak, but why? CNN. Retrieved March 8, 2014, from http://www.cnn.com/2014/01/14/world/asia/thailand-unrest-analysis-marshall/

McKelvey, B. (2011). Due Process Rights and the Targeted Killing of Suspected Terrorists: The Unconstitutional Scope of Executive Killing Power. 44 VAND. J. TRANSNAT'L L. 1353. Retrieved March 8, 2014, from http://www.vanderbilt.edu/jotl/manage/wp-content/uploads/mckelvey-pdf.pdf

McLean, D. (2004). Bin Laden transcript outlines plan to bankrupt U.S. through war, Bloomberg. Retrieved March 8, 2014, from http://www.bloomberg.com/apps/news?pid=newsarchive\&sid=aQwY7PFwX6oI

Memorandum opinion for the Deputy Counsel to the President (2001). The President's Constitutional Authority to Conduct Military Operations Against Terrorists and Nations Supporting Them.

Metropolitan Washington Airports Authority v. Citizens for the Abatement of Aircraft Noise, Inc., 501 U.S. 252 (1991).

New York Times Co. v. United States, 403 U.S. 713 (1971).

Nicaragua v. United States of America, International Court of Justice (1986).

OECD (n.d.). Bribery and Corruption. Retrieved March 8, 2014, from http://www.oecd.org/corruption/

Open Society Foundations. (2013). Globalizing Torture. Retrieved March 8, 2014, from $\mathrm{http} / / / \mathrm{www} . o p e n s o c i e t y$ foundations.org/sites/default/files/globalizing-torture-20120205.pdf

Paul, R. (2002). Illegal War Violates the Constitution. Retrieved March 8, 2014, from http://www.lewrockwell.com/1970/01/ron-paul/illegal-war-violates-the-constitution/

Paul, R. (2010). Supporting the War Instead of the Troops. Retrieved March 8, 2014, from http://www.ronpaul.com/2010-03-15/support-the-troops-end-the-war-in-afghanistan/

Pellerin, C. (2012). U.S., Thai Leaders Move Defense Alliance Into 21st Century. U.S. Department of Defense. Retrieved March 8, 2014, from http://www.defense.gov/news/newsarticle.aspx?id=118550 
People's Daily Online. (2011, April 25). Kunming-Singapore High-Speed Railway begins construction. Retrieved March 8, 2014, from http://english.people.com.cn/90001/90776/90882/7360790.html

Prakash, S. (2006). The Domestic War. Yale Law Journal Pocket Part. Retrieved March 8, 2014, from http://www.yalelawjournal.org/images/pdfs/39.pdf

Rakove, J. (2009). The Annotated U.S. Constitution and Declaration of Independence. USA: Harvard.

Randolph, R. S. (1986). The United States and Thailand: Alliance Dynamics 1950-85. Berkeley, CA: Institute of East Asian Studies, University of California Berkeley.

Relyea, H. (2001). National Emergency Powers. CRS Report for Congress. Retrieved March 8, 2014, from http://fpc.state.gov/documents/organization/6216.pdf

Rome Statute of the International Criminal Court. (1998).

Rowley, R. (2013). Dirty Wars [Motion picture]. Retrieved from at http://dirtywars.org/

Royal Thai Embassy Washington DC. (n. d.). An Overview of U.S.-Thai Relations. Retrieved March 8, 2014, from http://www.trade.gov/mas/ian/build/groups/public/@tg_ian/documents/webcontent/tg_ian_003364.pdf

Royal Thai Embassy Washington DC, Office of Commercial Affairs. (2011). Retrieved March 8, 2014, from http://www.commercethaiusa.org/oca/wp-content/uploads/PDF/ThailandStrategicPartnerCA0811.pdf

Ruth, R. (2010). In Buddha's Company. University of Hawaii Press. Retrieved March 8, 2014, from https://muse.jhu.edu/books/9780824860851

Sanford, S. (2013). Violence in Thailand's Deep South Escalates as Peace Talks Take Place. VOA. Retrieved March 8, 2014, from http://www.voanews.com/content/thailand-muslim-south-violence-peace-talks/ 1682231.html

Scahill, J. (2013). The Perpetual War. Moyers \& Company. Retrieved March 8, 2014, from http://billmoyers.com/2013/10/31/the-perpetual-war/

Shadbolt, P. (2013). Conflict in Buddhism: Violence for the sake of peace? The Buddhist Channel. Retrieved March 8, 2014, from http://www.buddhistchannel.tv/index.php?id=70,11417,0,0,1,0\#.UxgOOT-Swk4

Sheridan, K. (2013, October 15). Iraq Death Toll Reaches 500,000 Since Start Of U.S.-Led Invasion, New Study Says. Huffington Post. Retrieved March 7, 2014, from http://www.huffingtonpost.com/2013/10/15/iraqdeath-toll_n_4102855.html

Sovereign Immunity. (n. d.). Retrieved March 8, 2014 from http://www.lpa.state.mn.us/pdf/infopackets/ Sovereign\%20Immunity.pdf

Spolsky, B., \& Hult, F. (2008). The Handbook of Educational Linguistics. Hong Kong: Blackwell

TAT News. (2014). Thailand welcomed 26.7 million visitor arrivals in 2013, exceeding target. Retrieved March 8, 2014, from http://www.tatnews.org/thailand-welcomed-26-7-million-visitor-arrivals-in-2013-exceedingtarget

Thai-U.S. Treaty of Amity and Commerce. (1833).

Thailand Act for Enforcement of the Geneva Convention Relative to Treatment of Prisoners of War (1949).

Thailand Constitution.

Thailand Internal Security Act. (2008).

Thailand National Human Rights Commission Act. (1999).

Thailand Public Relations Department. (n. d.). Industry. Retrieved March 8, 2014, from http://thailand.prd.go.th/ ebook/inbrief/page.php?cid=8

Thomas W. McArthur et al v. Clark Clifford et al, 393 U.S. 1002, 89 S.Ct. 487, 21 L.Ed.2d 466 (1968).

Tomlinson, S. (2014, February 13). Ssssssemper Fi! U.S. Marines toughen up by drinking SNAKE BLOOD and beheading chickens with their teeth in gruesome survival training in Thai jungle. Mail on Sunday. Retrieved March 8, 2014, from http://www.dailymail.co.uk/news/article-2558569/Drinking-COBRA-BLOODbeheading-chickens-teeth-U-S-Marines-gruesome-survival-training-Thai-jungle.html

UNOHCHR. (2013). Pakistan. Statement by the UN Special Rapporteur on human rights and counter-terrorism. Retrieved March 8, 2014, from http://www.ohchr.org/en/NewsEvents/Pages/DisplayNews.aspx?NewsID= 13148\&LangID $=\mathrm{E}$ 
UN Security Council Resolution 678. (1990).

UN Security Council Resolution 1441. (2002).

United Nations Charter. (1945).

United States Constitution. (1789).

United States Espionage Act 18 U.S. Code § 794.

United States Supreme Court. (2014). The Court and Constitutional Interpretation. Retrieved March 8, 2014, from http://www.supremecourt.gov/about/constitutional.aspx

U.S. Census Bureau. (2014). Trade in Goods with Thailand. Retrieved March 8, 2014, from $\mathrm{http}: / / \mathrm{www} . c e n s u s . g o v /$ foreign-trade/balance/c5490.html

U.S. Department of State (n.d.). Milestones 1945-52. Office of the Historian. Retrieved March 8, 2014, from http://history.state.gov/milestones/1945-1952/korean-war-2

U.S. Department of State. (n. d.). Milestones 1953-1960. Office of the Historian. Retrieved March 8, 2014, from http://history.state.gov/milestones/1953-1960/seato

U.S. Department of State Office of the Historian. (n. d.). A Guide to the United States' History of Recognition, Diplomatic, and Consular Relations, by Country, since 1776: Thailand. Retrieved March 8, 2014, from http:/history.state.gov/countries/thailand

U.S. Embassy Bangkok. (n. d.). Timeline of U.S.-Thai Relations. Retrieved March 8, 2014 from http://bangkok.usembassy.gov/relation/timeline.html

U.S. Embassy Bangkok (2014). Travel Alert for Thailand. Retrieved March 8, 2014 from http://bangkok.usembassy.gov/021414_thailand_travel_alert.html

U.S. International Trade Administration. (2014). Top U.S. Trade Partners. Retrieved March 8, 2014 from http://www.trade.gov/mas/ian/build/groups/public/@tg_ian/documents/webcontent/tg_ian_003364.pdf

U.S. National Emergencies Act. (1976).

U.S. Public Law 107-40. (2001).

U.S. War Powers Resolution. (1973).

Vienna Convention on the Law of Treaties. (1969).

VOA (2011). Thai Royalists Protest Against U.S., UN Interference. Retrieved March 8, 2014, from http://www.voanews.com/content/thai-royalists-protest-against-us-un-interference-135727853/149618.html

Williams, R. (2011). Dangerous Precedent: America's Illegal War in Afghanistan. 33 U PA J Int'l L, pp563-613. Retrieved March 8, 2014, from https://www.law.upenn.edu/live/files/145-williams33upajintll5632011pdf

World Vision. (2009). Fact Sheet: Labour Exploitation. Retrieved March 7, 2014, from http://www.worldvision.com.au/Libraries/DTL_fact_sheets/Factsheet_Labour.pdf

Yafei, H. (2014, February 3). Overseas Chinese business can build bridges for the new maritime Silk Road. South China Morning Post. Retrieved March 8, 2014, from http://www.scmp.com/comment/insightopinion/article/1420000/overseas-chinese-business-can-build-bridges-new-maritime

Yick Wo v. Hopkins, 118 U.S. 356 (1886).

Yoo, J. (2012). War Powers Belong to the President. ABA Journal. Retrieved March 8, 2014, from http://www.abajournal.com/magazine/article/war_powers_belong_to_the_president

Youngstown Sheet \& Tube Co. v. Sawyer, 343 U.S. 579 (1952).

\section{Notes}

Note 1. Cambodia v. Thailand, International Court of Justice (Nov. 11, 2013), http://www.icj-cij.org/docket/files/151/17704.pdf

Note 2. Established in 1967, and expanded thereafter, ASEAN is composed of ten nations - Brunei, Cambodia, Indonesia, Laos, Malaysia, Myanmar, Philippines, Singapore, Thailand, Vietnam. Aims and purposes include improving regional trade, political, security, social, and cultural cooperation. See ASEAN Secretariat, Overview (2012), http://www.asean.org/asean/about-asean 
Note 3. ASEAN Secretariat, ASEAN Economic Community (2012), http://www.asean.org/communities/asean -economic-community

Note 4. Congressional Record Volume 144, Number 56, Pages H2944-H2978 (May 7, 1998), http://www.gpo.gov/fdsys/pkg/CREC-1998-05-07/pdf/CREC-1998-05-07.pdf

Note 5. The 1836 Treaty of Amity and Commerce was the first treaty the United States made with any Asian nation.

Note 6. U.S. Department of State Office of the Historian, A Guide to the United States' History of Recognition, Diplomatic, and Consular Relations, by Country, since 1776: Thailand, http://history.state.gov/countries/thailand

Note 7. U.S. Embassy Bangkok, Timeline of U.S.-Thai Relations, http://bangkok.usembassy.gov/relation/ timeline.html

Note 8. "...globalization overlaps the neocolonial process of economic and political domination of the empire..." Bernard Spolsky and Francis Hult, The Handbook of Educational Linguistics, p206 (2008), Hong Kong: Blackwell

Note 9. U.S. Const., art. I §8 (1787)

Note 10. U.S. Const. art. II, $\S 3$

Note 11. U.S. Const. art. II, $\S 1$

Note 12. U.S. Const. art. VI, cl. 2

Note 13. U.S. Const. art. II, §2

Note 14. War Powers Resolution (1973)

Note 15. National Emergencies Act (1976)

Note 16. Public Law 107-40 (2001)

Note 17. Metropolitan Washington Airports Authority v. Citizens for the Abatement of Aircraft Noise, Inc., 501 U.S. 252 (1991)

Note 18. Yick Wo v. Hopkins, 118 U.S. 356 (1886)

Note 19. U.S. Const. amend. 14, §1

Note 20. Hamdi v. Rumsfeld, 542 U.S. 507 (2004); New York Times Co. v. United States, 403 U.S. 713 (1971); Ernest Da Costa v. Melvin R. Laird, Individually, and as Secretary of Defense of the United States, 405 U.S. 979 (1972); Gary F. Mottola et al v Richard M. Nixon and Melvin Laird, 464 F. 2 d 178 (1972); Commonwealth of Massachusetts v Melvin R. Laird, 400 U.S. 886 (1970); Elizabeth Holtzman et al v James R. Schlesinger et al, 414 U.S. 1304, 94 S.Ct. 1, 38 L.Ed.2d 18 (1973); Youngstown Sheet \& Tube Co. v. Sawyer, 343 U.S. 579 (1952)

Note 21. Thomas W. McArthur et al v Clark Clifford et al, 393 U.S. 1002, 89 S.Ct. 487, 21 L.Ed.2d 466 (1968)

Note 22. The President's Constitutional Authority to Conduct Military Operations Against Terrorists and Nations Supporting Them (2001), Memorandum opinion for the Deputy Counsel to the President, retrieved February 2, 2014 at http://www.justice.gov/olc/warpowers925.htm

Note 23. Nicaragua v. USA (1986), retrieved March 12, 2014 from http://www.icj-cij.org/docket/index. php? sum $=367 \&$ code $=$ nus $\& \mathrm{p} 1=3 \& \mathrm{p} 2=3 \&$ case $=70 \& \mathrm{k}=66 \& \mathrm{p} 3=5$

Note 24. U.S. Const. art. VI, cl. 2

Note 25. Vienna Convention on the Law of Treaties, art. 27 (1969); United States signed but withheld ratification

Note 26. UN Security Council Resolutions (2002), retrieved February 5, 2014 from http://www.un.org/Docs/scres/2002/sc2002.htm

Note 27. Rome Statute of the International Criminal Court (1998)

Note 28. Nicaragua v. United States of America, International Court of Justice (1986)

Note 29. Clinton v. Jones (95-1853), 520 U.S. 681 (1997).

Note 30. Quote from former Representative Lee Hamilton. See Alan Greenblatt, Why the War Powers Act doesn't work, NPR (Jun. 16, 2011), http://www.npr.org/2011/06/16/137222043/why-the-war-powers-act-doesnt -work 
Note 31. Thai Const. $\$ 79$

Note 32. "The State shall protect and uphold the institution of kingship and the independence and integrity of its jurisdictions...” Thai Const. §77

Note 33. Thai National Human Rights Commission Act, §15 (1999)

Note 34. Thai Const. $\$ 82$

Note 35. Geneva Convention (III) on Prisoners of War (1949)

Note 36. Thailand Act for Enforcement of the Geneva Convention Relative to Treatment of Prisoners of War (1949)

Note 37. Thai Internal Security Act, $\S 15$ (2008)

Note 38. Thai Const. $§ 77$

Note 39. 18 U.S. Code $\S 794$ reads "Whoever, with intent or reason to believe that it is to be used to the injury of the United States or to the advantage of a foreign nation, communicates, delivers, or transmits, or attempts to communicate, deliver, or transmit, to any foreign government, or to any faction or party or military or naval force within a foreign country, whether recognized or unrecognized by the United States, or to any representative, officer, agent, employee, subject, or citizen thereof, either directly or indirectly, any document, writing, code book, signal book, sketch, photograph, photographic negative, blueprint, plan, map, model, note, instrument, appliance, or information relating to the national defense, shall be punished by death or by imprisonment for any term of years or for life..." A Thai Espionage Act would more appropriately omit the first dependent clause.

Note 40. China-ASEAN Free Trade Agreement (2010)

\section{Copyrights}

Copyright for this article is retained by the author(s), with first publication rights granted to the journal.

This is an open-access article distributed under the terms and conditions of the Creative Commons Attribution license (http://creativecommons.org/licenses/by/3.0/). 